\title{
Pattern of Public Expenditure on Social Sector in India
}

\section{OPEN ACCESS}

Manuscript ID:

ECO-2020-09013515

Volume: 9

Issue: 1

Month: December

Year: 2020

P-ISSN: 2319-961X

E-ISSN: 2582-0192

Received: 20.09 .2020

Accepted: 25.10 .2020

Published: 01.12.2020

Citation:

Premalatha, R. "Pattern of Public Expenditure on Social Sector in India." Shanlax International Journal of Economcis, vol. 9, no. 1, 2020, pp. 57-62.

DOI: https://doi.org/10.34293/ economics.v9i1.3515

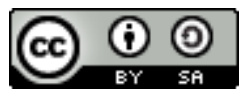

This work is licensed under a Creative Commons Attribution-ShareAlike 4.0 International License

\section{R. Premalatha}

Assistant Professor, Department of Economics

VELS Institute of Science, Technology and Advanced Studies, Chennai, Tamil Nadu, India

(D) https://orcid.org/0000-0002-1928-1100

\begin{abstract}
Human capital also enhances the productivity of high-technology physical capital. Available empirical evidence indicates that all countries that have managed persistent growth in income have also had large increases in the education and training of their labor forces. Empirical studies in the Indian context also reveal investments in human capital have a significant impact on economic growth. Like many other developing countries, the Government of India's key policy documents, including economic reforms, have identified poverty eradication/alleviation and social development as two main challenges and expressed the government's commitment towards social development and eradication of poverty. Indian government's gradual adoption of marketoriented economic reform policies in the mid-1980s was accompanied by an expansionist fiscal strategy to counterbalance the redistributive effect of liberalization. These economic and political developments have tended to strongly influence social sector policies in India. If the expenditure is diverted towards development activities, it will promote the process development of the state. It becomes essential to study the patterns of social sector expenditure in India at national and state levels to ascertain how the social sector has been managed by the governments in India and to what extent the central and state governments in India have fulfilled their responsibility of developing the social sector in India.
\end{abstract}

Keywords: Social Sector Expenditure, Economic Impact, Development, Government, India, Human Resources.

\section{Introduction}

Since the 1960s, human resources have been perceived as a critical factor in clarifying contrasts inefficiency and disparity among countries. Expenditures on instruction and wellbeing produce human resources, which brings economic returns separately and afterward aggregately. The hidden reasoning of a human resources viewpoint is that human resources through amassing of information and abilities improve the profitability of economic operators, and this, like this, improves the allocative proficiency as more gifted specialists designate assets successfully over the gainful chances. Human resources likewise upgrade the profitability of high-innovation physical capital. Accessible exact proof demonstrates that all nations that have overseen tenacious development in salary have additionally had enormous increments in the instruction and preparation of their workforces. Exact investigations in the Indian setting likewise uncover speculations on human resources significantly affect economic development. By this expansive reasoning, it is conceived that administration approaches in the social sector vitally impact the nation's general improvement measure.

In the same way as other non-industrial nations, the Government of India's key approach reports, including economic changes, have distinguished poverty annihilation/mitigation and social improvement as two fundamental difficulties and communicated the administration's dedication towards the social turn of events and destruction of poverty. Indian government's continuous appropriation financial methodology to offset the redistributive impact of progression. 
These economic and political improvements have will, in general, firmly impact social sector approaches in India. Taking into account that poverty decrease and advancement of comprehensive development are two significant approach needs of progressive governments in the 2000s, this article investigations social sector expenditure caused by the focal and state governments as far as its measurements, patterns, and synthesis. In this investigation, social sector expenditure is characterized as the complete public expenditure caused under the headings of social administrations and country improvement given in local and state spending plans.

\section{Objectives of the Study}

1. To study the trend in social sector expenditure of India $1988-89$ to $2010-11$.

2. To calculate the determinants of social sector expenditure in India during 1988-89 to 2010-11.

\section{Statement of the Problem}

The expenditure on the social sector needs exceptional consideration. The current study means to dissect the pattern of expenditure of the legislature of India towards social sector improvements and its suggestion. This would empower us to comprehend the advancement. On the off chance that the expenditure is redirected towards improvement exercises, it will advance the cycle advancement of the state. While more subsidies distributed for nonadvancement expenditure will be exceptionally disadvantageous to the improvement of the state, more over it is important to analyze the patterns of social sector expenditure with net state homegrown result of the state.

\section{Period of Study}

The analysis of public expenditure in Tamil Nadu has been carried through twelve years, from 1988-89 to 2010-11.

\section{Analysis of Data}

The Constitution of India sets out the division of duties among the middle and states and places the fundamental duty regarding the social sector expenditure on the states. The wellbeing sector and most provincial improvement issues fall under the obligation rundown of states. In contrast, training, work, and government assistance issues go under the simultaneous rundown making these the joint duty of focus and states. Accordingly, it gets basic to examine the examples of social sector expenditure in India at public and state levels to find out how the social sector has been overseen by the legislatures in India and how much the focal and state government in India have satisfied their obligation of building up the social sector in India. Table 1 speaks to consolidated social sector expenditure of focus and states just as the commitment of focus and states towards social sector expenditure in India during 1988-89 to 2010-11. The year-on-year development in social sector expenditure in percent is additionally portrayed in this table. The middle contributes around 16 to 36 percent, while states contribute around 64 to 84 percent of joined social sector expenditure from 1988-89 to 2010-11. Being the established duty of states, the dominant part of the social sector expenditure is caused by the states. The states' offer in social sector expenditure shows a declining pattern while focus' offer is ascending during this period.

Table 1: Social Sector Expenditure (SSE) at National Level (in Crore)

\begin{tabular}{|c|c|c|c|c|}
\hline Year & Centre & States & $\begin{array}{l}\text { Total } \\
\text { SSE }\end{array}$ & $\begin{array}{c}\text { Year-on- } \\
\text { Year Growth } \\
\text { in SSE }(\%)\end{array}$ \\
\hline $1988-89$ & $\begin{array}{l}18715 \\
(19.1)\end{array}$ & $\begin{array}{l}78142 \\
(80.9) \\
\end{array}$ & 96857 & - \\
\hline $1989-90$ & $\begin{array}{l}25337 \\
(23.8)\end{array}$ & $\begin{array}{l}81113 \\
(76.2)\end{array}$ & 106450 & 9.9 \\
\hline $1990-91$ & $\begin{array}{l}18406 \\
(17.2)\end{array}$ & $\begin{array}{l}88732 \\
(82.8)\end{array}$ & 107138 & 0.6 \\
\hline $1991-92$ & $\begin{array}{l}17828 \\
(17.2)\end{array}$ & $\begin{array}{l}85909 \\
(82.8)\end{array}$ & 103737 & -3.2 \\
\hline $1992-93$ & $\begin{array}{l}17459 \\
(16.3)\end{array}$ & $\begin{array}{l}89601 \\
(83.7)\end{array}$ & 107060 & 3.2 \\
\hline 1993-94 & $\begin{array}{l}24343 \\
(21.0)\end{array}$ & $\begin{array}{l}91359 \\
(79.0)\end{array}$ & 115702 & 8.1 \\
\hline 1994-95 & $\begin{array}{l}26568 \\
(22.2)\end{array}$ & $\begin{array}{l}93374 \\
(77.8)\end{array}$ & 119942 & 3.7 \\
\hline $1995-96$ & $\begin{array}{l}29869 \\
(23.2)\end{array}$ & $\begin{array}{l}99907 \\
(76.8)\end{array}$ & 129776 & 8.2 \\
\hline
\end{tabular}




\begin{tabular}{|c|c|c|c|c|}
\hline $1996-97$ & $\begin{array}{c}29964 \\
(22.1)\end{array}$ & $\begin{array}{c}105475 \\
(77.9)\end{array}$ & 135439 & 4.4 \\
\hline $1997-98$ & $\begin{array}{c}35065 \\
(23.7)\end{array}$ & $\begin{array}{c}112811 \\
(76.3)\end{array}$ & 147876 & 9.2 \\
\hline $1998-99$ & $\begin{array}{c}37393 \\
(22.9)\end{array}$ & $\begin{array}{c}125660 \\
(77.1)\end{array}$ & 163053 & 10.3 \\
\hline $1999-00$ & $\begin{array}{c}39971 \\
(22.3)\end{array}$ & $\begin{array}{c}138887 \\
(77.7)\end{array}$ & 178858 & 9.7 \\
\hline $2000-01$ & $\begin{array}{c}41695 \\
(22.0)\end{array}$ & $\begin{array}{c}148114 \\
(78.0)\end{array}$ & 189809 & 6.1 \\
\hline $2001-02$ & $\begin{array}{c}51731 \\
(26.1)\end{array}$ & $\begin{array}{c}146726 \\
(73.9)\end{array}$ & 198457 & 4.6 \\
\hline $2002-03$ & $\begin{array}{c}65318 \\
(30.9)\end{array}$ & $\begin{array}{c}146093 \\
(69.1)\end{array}$ & 211411 & 6.5 \\
\hline $2003-04$ & $\begin{array}{c}67451 \\
(30.4)\end{array}$ & $\begin{array}{c}154564 \\
(69.6)\end{array}$ & 222015 & 5.0 \\
\hline $2004-05$ & $\begin{array}{c}67903 \\
(29.2)\end{array}$ & $\begin{array}{c}164875 \\
(70.8)\end{array}$ & 232778 & 4.8 \\
\hline $2005-06$ & $\begin{array}{c}76941 \\
(29.5)\end{array}$ & $\begin{array}{c}184101 \\
(70.5)\end{array}$ & 261042 & 12.1 \\
\hline $2006-07$ & $\begin{array}{c}93864 \\
(31.6)\end{array}$ & $\begin{array}{c}202933 \\
(68.4)\end{array}$ & 296797 & 13.7 \\
\hline $2007-08$ & $\begin{array}{c}99381 \\
(30.1)\end{array}$ & $\begin{array}{c}230469 \\
(69.9)\end{array}$ & 329850 & 11.1 \\
\hline $2008-09$ & $\begin{array}{c}141493 \\
(34.8)\end{array}$ & $\begin{array}{c}265584 \\
(65.2)\end{array}$ & 407077 & 23.4 \\
\hline $2009-10$ & $\begin{array}{c}152269 \\
(33.8)\end{array}$ & $\begin{array}{c}298375 \\
(66.2)\end{array}$ & 450644 & 10.7 \\
\hline $2010-11$ & $\begin{array}{c}176069 \\
(36.0)\end{array}$ & $\begin{array}{c}313342 \\
(64.0)\end{array}$ & 489411 & 8.6 \\
\hline
\end{tabular}

Note: Figures in parenthesis are percentage shares

Source: Computed from data in Combined Finance and Revenue Accounts of the Union and State Governments, GOI (various years).

Public expenditure on the social sector by focus and states can likewise be ordered into income and capital heads of records. Income expenditure comprises repetitive expenditure on wages and pays rates and general working sector improvement programs. Table 2 shows the public spending of focus and states on the social sector by income and capital record. Around 89 to 94.5 percent of the complete social sector expenditure has been caused on income account while the capital expenditure on social sector goes from 5.5 to 11 percent. The social sector

expenditure on income account has demonstrated a decay while an expansion has been found in the social sector expenditure on capital record during $1988-89$ to $2010-11$. It is seen that social sector expenditure in India is overwhelmingly on income account as wages and compensations and so forth, and a limited quantity is spent on the advancement of a physical framework for the social sector as capital expenditure establishes a minuscule extent of allout social sector expenditure showing generally low significance given to interest in the social sector.

Table 2: Social Sector Expenditure at National Level by Revenue and Capital Account (in crore)

\begin{tabular}{|c|c|c|c|}
\hline Year & Revenue & Capital & Total \\
\hline $1988-89$ & 90106 (93.3) & $6751(6.7)$ & 96857 \\
\hline $1989-90$ & 99106 (93.1) & $7344(6.9)$ & 106450 \\
\hline $1990-91$ & $100238(93.6)$ & $6900(6.4)$ & 107138 \\
\hline $1991-92$ & 97094 (93.6) & $6643(6.4)$ & 103737 \\
\hline $1992-93$ & 99852 (93.3) & $7208(6.7)$ & 107060 \\
\hline 1993-94 & $109063(94.3)$ & $6639(5.7)$ & 115702 \\
\hline 1994-95 & $111896(93.3)$ & $8046(6.7)$ & 119942 \\
\hline $1995-96$ & $122555(94.4)$ & $7221(5.6)$ & 129776 \\
\hline $1996-97$ & $127567(94.2)$ & $7872(5.8)$ & 135439 \\
\hline $1997-98$ & $138978(94.0)$ & $8898(6.0)$ & 147876 \\
\hline 1998-99 & $153348(94.0)$ & $9705(6.0)$ & 163053 \\
\hline 1999-00 & $168588(94.3)$ & $10270(5.7)$ & 178858 \\
\hline 2000-01 & $175593(92.5)$ & $14216(7.5)$ & 189809 \\
\hline 2001-02 & $182835(92.1)$ & $15622(7.9)$ & 198457 \\
\hline $2002-03$ & $196411(92.9)$ & $15000(7.1)$ & 211411 \\
\hline 2003-04 & $204490(92.1)$ & 17525 (7.9) & 222015 \\
\hline 2004-05 & $214306(92.1)$ & 18472 (7.9) & 232778 \\
\hline $2005-06$ & $237649(91.0)$ & $23393(9.0)$ & 261042 \\
\hline 2006-07 & $271036(91.3)$ & $25761(8.7)$ & 296797 \\
\hline 2007-08 & $295202(89.5)$ & $34648(10.5)$ & 329850 \\
\hline 2008-09 & 364819 (89.6) & $42258(10.4)$ & 407077 \\
\hline $2009-10$ & $405624(90.0)$ & $45020(10.0)$ & 450644 \\
\hline 2010-11 & $436483(89.2)$ & $52928(10.8)$ & 489411 \\
\hline
\end{tabular}

Note: Figures in parenthesis are percentage shares

Source: Computed from data in Combined Finance and Revenue Accounts of the Union and State Governments, GOI (various years).

Table 3 both portray the joined public expenditure on the social sector of focus and states as an extent of GDP just as an extent of total public expenditure. As 
an extent of GDP, India is spending under $10 \%$ of its GDP on the social sector during 1988-89 to 2010-11. The portion of GDP brought about on social sector has ascended from 7.28 percent in 1988-89 to its most significant level of 9.41 percent in 2009-10 then it has declined imperceptibly to 9.26 percent in 2010 11 Center is contributing around 1 to 3.5 percent of GDP towards social sector while states are causing around 5 to 6.5 percent of GDP on the social sector. It is seen that the middle's offer has demonstrated an expanding pattern with certain vacillations. In contrast, no significant changes have been found in the patterns of states' offer in the general social sector expenditure as a percent of GDP from 198889 to $2010-11$.

Table 3: Social Sector Expenditure (SSE) at National Level

\begin{tabular}{|c|c|c|c|c|c|c|c|c|c|}
\hline \multirow{2}{*}{ Year } & \multicolumn{3}{|c|}{ SSE as per cent of GDP } & \multicolumn{3}{|c|}{$\begin{array}{c}\text { SSE as per cent of Aggregate } \\
\text { Public Expenditure }\end{array}$} & \multicolumn{2}{|c|}{ Real Per Capita SSE (in) } \\
\cline { 2 - 11 } & Centre & States & Total & Centre & States & Total & Centre & States & Total \\
\hline $1988-89$ & 1.41 & 5.87 & 7.28 & 4.19 & 17.49 & 21.68 & 231 & 966 & 1197 \\
\hline $1989-90$ & 1.80 & 5.75 & 7.55 & 5.18 & 16.61 & 21.79 & 306 & 982 & 1288 \\
\hline $1990-91$ & 1.24 & 5.96 & 7.20 & 3.70 & 17.82 & 21.52 & 217 & 1047 & 1264 \\
\hline $1991-92$ & 1.19 & 5.71 & 6.90 & 3.60 & 17.33 & 20.93 & 206 & 994 & 1200 \\
\hline $1992-93$ & 1.10 & 5.65 & 6.75 & 3.36 & 17.26 & 20.62 & 198 & 1016 & 1214 \\
\hline $1993-94$ & 1.47 & 5.50 & 6.97 & 4.49 & 16.85 & 21.34 & 270 & 1014 & 1284 \\
\hline $1994-95$ & 1.50 & 5.27 & 6.77 & 4.65 & 16.34 & 20.99 & 289 & 1016 & 1305 \\
\hline $1995-96$ & 1.57 & 5.24 & 6.81 & 5.18 & 17.30 & 22.48 & 319 & 1066 & 1385 \\
\hline $1996-97$ & 1.46 & 5.15 & 6.61 & 4.92 & 17.34 & 22.26 & 314 & 1104 & 1418 \\
\hline $1997-98$ & 1.64 & 5.29 & 6.93 & 5.22 & 16.78 & 22.00 & 360 & 1159 & 1519 \\
\hline $1998-99$ & 1.65 & 5.55 & 7.20 & 5.30 & 17.80 & 23.10 & 377 & 1267 & 1644 \\
\hline $1999-00$ & 1.63 & 5.63 & 7.26 & 5.05 & 17.57 & 22.62 & 396 & 1375 & 1771 \\
\hline $2000-01$ & 1.64 & 5.78 & 7.42 & 5.27 & 18.72 & 23.99 & 405 & 1439 & 1844 \\
\hline $2001-02$ & 1.93 & 5.47 & 7.40 & 6.17 & 17.51 & 23.68 & 494 & 1400 & 1894 \\
\hline $2002-03$ & 2.35 & 5.24 & 7.59 & 7.55 & 16.89 & 24.44 & 614 & 1373 & 1987 \\
\hline $2003-04$ & 2.25 & 5.14 & 7.39 & 7.18 & 16.46 & 23.64 & 624 & 1431 & 2055 \\
\hline $2004-05$ & 2.09 & 5.09 & 7.18 & 7.08 & 17.18 & 24.26 & 619 & 1502 & 2121 \\
\hline $2005-06$ & 2.17 & 5.20 & 7.37 & 7.49 & 17.92 & 25.41 & 690 & 1653 & 2343 \\
\hline $2006-07$ & 2.42 & 5.25 & 7.67 & 8.30 & 17.92 & 26.22 & 831 & 1796 & 2627 \\
\hline $2007-08$ & 2.34 & 5.42 & 7.76 & 7.90 & 18.32 & 26.22 & 867 & 2011 & 2878 \\
\hline $2008-09$ & 3.20 & 6.02 & 9.22 & 9.90 & 18.57 & 28.47 & 1217 & 2286 & 3503 \\
\hline $2009-10$ & 3.19 & 6.22 & 9.41 & 10.26 & 20.12 & 30.38 & 1292 & 2533 & 3825 \\
\hline $2010-11$ & 3.33 & 5.93 & 9.26 & 11.20 & 19.93 & 31.13 & 1474 & 2623 & 4097 \\
\hline
\end{tabular}

Source: Computed from data in Combined Finance and Revenue Accounts of the Union and State Governments, GOI (various years); Handbook of Statistics on Indian Economy 2013-14, RBI (2014);

World Economic Outlook Database 2014, IMF (2014).

As a percent of total public expenditure, India is spending around 20.5 to 31.5 percent on the social sector, out of which states contribute around 16 to 20.5 percent. In comparison, the commitment of focus goes from 3 to 11.5 percent. The joined social sector expenditure as the level of total public expenditure shows an expansion of more than 43 percent (from 21.68 percent in 1988-89 to 31.13 percent in 2010-11) while the portion of states in social sector expenditure has expanded by 14 percent just (from 17.49 percent in 1988-89 to 19.93 percent in 2010-11) though the portion of focus has 
expanded by very nearly 167 percent during 198889 to $2010-11$. This examination uncovers that social sector expenditure as far as both as the level of GDP just as the level of total public expenditure has demonstrated an expanding pattern since 200405 till 2010-11 because of the explanation that some significant activities like "Bharat Nirman program, National Rural Employment Guarantee Scheme, National Rural Health Mission, Jawaharlal Nehru National Urban Renewal Mission, assignment to Sarva Shiksha Abhiyan, Mid-day Meal Scheme" and so on The middle's offer in the general social sector expenditure as the level of GDP just as the level of total public expenditure has been expanding throughout the years during the time of the study. In the event of a piece of states' social sector expenditure, 'instruction, sports, craftsmanship, and culture' turns into the primary head as the states are bringing about the most noteworthy measure of public expenditure both as far as the level of GDP just as the level of total public expenditure on this head. A sharp decrease in the portion of 'rustic turn of events' head in the states' social sector expenditure as a percent of GDP has been found during 1988-89 to 1989-90 as against the noteworthy increment in the portion of this head in the middle's social sector expenditure as a percent of GDP during a similar period with the explanation that the complex increment in the expenditure of the focal government under the minor head provincial business has been trailed by a critical cut in the state's expenditure under a similar minor head.

\section{Conclusion}

The aforementioned investigation uncovers that most of the social sector expenditure in India is met by the states, the equivalent being their established obligation. In any case, the portion of the states in the general social sector expenditure has been declining during the study. Even though the middle's offer in the social sector expenditure is moderately little, in any case, it has been expanding over the period under examination. The year-on-year development in the social sector expenditure in India has been generally unpredictable. The legislatures in India have concurred generally low significance to interest in the social sector framework as reflected in the way that the capital expenditure establishes a little extent in the general social sector expenditure in India. The genuine per capita open expenditure on the social sector has demonstrated a consistent increment over the time of study while the pace of development in the middle's genuine per capita social sector expenditure has been higher than the pace of development in the states' genuine per capita open expenditure on the social sector.

\section{References}

Abizadeh, Sohrab, and John Gray. "Wagner's Law: A Pooled Time-series, Cross Section Comparison." National Tax Journal, vol. 38, 1983, pp. 209-216.

Ahsan, Syed M. et al. "Co-Integration and Wagner's Hypothesis: Time Series Evidence for Canada." Applied Economics, vol. 28, no. 8, 1996, pp. 1055-1058.

Anthony S. Courakis, et al. "Public Expenditure Growth in Greece and Portugal: Wagner's Law and Beyond." Applied Economics, vol. 25, no. 1, 1993, pp. 125-134.

Anyanwn, John C. “An Analysis of Nigeria's Public Expenditure: 1970-1991.” Anvesak, vol. 24, no. 1-2, 1994, pp. 109-123.

Bhattacharya, Govind. "Intra State Economic Disparties in Government Expenditure." Economic and Political Weekly, vol. 44, no. $26 \& 27,2009$.

Diamond, Jack. "Government Expenditure and Growth." Southern Economist, vol. 29, no. $22,1991$.

Frank, Gould. "Development of Public Expenditure in Western, Industrialized Countries: A Comparative Analysis." Public Financel Finances Publiques, vol. 38, no. 1, 1983, pp. 38-69.

Gandhi, Ved P. "Wagner's Law of Public Expenditure: Do Recent cross Section Studies Confirm it?." Public Finance/Finances Publiques, vol. 26, no. 1, 1971, pp. 44-56.

Hugh, Dalton. Principles of Public Finance. Routledge, 2003.

Kaur, Balbir, and Sangita Misra. "Social Sector Expenditure and Attainments: An Analysis of Indian States." Reserve Bank of India 
Occasional Papers, vol. 24, no. 1 \& 2, 2003, Reddy, K.N. "Determinants of Growth of pp. 105-134.

Khan, Ashfaque H. "Wagner's Law and the Developing Economy: A Time Series Evidence from Pakistan." The Indian Economic Journal, vol. 38, 1990.

Landau, Daniel. "Government Expenditure and Economic Growth: A Cross Country Study." Southern Economic Journal, vol. 49, no. 3, 1983, pp. 783-792.

Madhavachari, R. "Wagner's Law of Public Expenditure - An Empirical Test." Margin, vol. 14, no. 2, 1982.

Ram, Rati. “A Multicountry Perspective Causality between Government Revenue and Government Expenditure." Public Finance = Finances Publiques, vol. 43, no. 1, 1988, pp. 261-270.

Ram, Rati. "Causality between Income and Government Expenditure: A Broad International Perspective." Public Finance = Finances Publiques, vol. 41, no. 3, 1986, pp. 393-414.

Government Expenditure in India." Indian Journal of Public Administration, vol. 34, no. 2, 1988, pp. 227-248.

Roy, K.C., and C.A. Tisdell. "Property Rights in Women's Empowerment in Rural India: A Review, Social Economics, Policy and Development," Working Paper No.14, 2000.

Roy, K.C. and C.A. Tisdell. "Property Rights in Women's Empowerment in Rural India: A Review." International Journal of Social Economics, vol. 29, no. 4, 2002, pp. 315-334.

Roy, Sanchari. "Empowering Women: Inheritance Rights and Female Education in India." Working Paper Series, 2011.

Rutherford, Malcolm. Institutions in Economics- The Old and the New Institutionalism. Cambridge University Press, 1996.

Sahni, Balvir S., and Balvir Singh. "On the Causal Directions between National Income and Government Expenditure in Canada." Public Finance/Finances Publiques, vol. 39, no. 3, 1984, pp. 359-373.

Thimmaiah. "Growth of Public Expenditure in Karnataka.” Southern Economist, 1977.

\section{Author Details}

R. Premalatha, Assistant Professor, Department of Economics, VELS Institute of Science, Technology and Advanced Studies, Chennai, Tamil Nadu, India, Email ID: premalatha044@gmail.com 